\title{
Recent developments in the genetics of childhood epileptic encephalopathies: impact in clinical practice
}

\author{
Desenvolvimentos recentes na genética das encefalopatias epilépticas da infância: \\ impacto na prática clínica \\ Marina C. Gonsales', Maria Augusta Montenegro², Camila V. Soler¹, Ana Carolina Coan², Marilisa M. \\ Guerreiro², Iscia Lopes-Cendes ${ }^{1}$
}

\begin{abstract}
Recent advances in molecular genetics led to the discovery of several genes for childhood epileptic encephalopathies (CEEs). As the knowledge about the genes associated with this group of disorders develops, it becomes evident that CEEs present a number of specific genetic characteristics, which will influence the use of molecular testing for clinical purposes. Among these, there are the presence of marked genetic heterogeneity and the high frequency of de novo mutations. Therefore, the main objectives of this review paper are to present and discuss current knowledge regarding i) new genetic findings in CEEs, ii) phenotype-genotype correlations in different forms of CEEs; and, most importantly, iii) the impact of these new findings in clinical practice. Accompanying this text we have included a comprehensive table, containing the list of genes currently known to be involved in the etiology of CEEs.
\end{abstract}

Keywords: Dravet syndrome, Ohtahara syndrome, West syndrome, Lennox-Gastaut syndrome, Doose syndrome, Landau-Kleffner syndrome.

\section{RESUMO}

Os avanços recentes em genética molecular permitiram a descoberta de vários genes para encefalopatias epilépticas da infância (EEls). À medida que o conhecimento sobre os genes associados a este grupo de doenças se desenvolve, torna-se evidente que as EEls apresentam uma série de características genéticas específicas, o que influencia o uso do teste molecular para fins clínicos. Entre as EEls, há a presença de acentuada heterogeneidade genética e alta frequência de mutações de novo. Assim, os principais objetivos deste trabalho de revisão são apresentar e discutir o conhecimento atual a respeito de i) novas descobertas em genética molecular das EEls, ii) correlações fenótipo-genótipo nas diferentes formas de EEls; e, mais importante, iii) o impacto desses novos achados genéticos na prática clínica. Acompanhando o texto, incluímos uma tabela contendo a lista de genes conhecidos atualmente como envolvidos na etiologia da EEls.

Palavras-chave: síndrome de Dravet, síndrome de Ohtahara, sindrome de West, síndrome de Lennox-Gastaut, síndrome de Doose, sindrome de Landau-Kleffner.

The encephalopathic effects of epileptic activity may occur in association with any form of epilepsy; however, it is more often present in a number of syndromes called childhood epileptic encephalopathies (CEEs). CEEs are conditions in which "the epileptic activity itself may contribute to severe cognitive and behavioral impairment above and beyond what might be expected from the underlying pathology alone (e.g., cortical malformation), and these can worsen over time"1.
Although the damaging effect of seizures can potentially happen in any form of epilepsy, in some syndromes this impairment is virtually always present. According to current classification ${ }^{1}$, the following syndromes are considered CEEs: early myoclonic encephalopathy (EME), Ohtahara syndrome (OS), epilepsy of infancy with migrating focal seizures (EIMFS), West syndrome (WS), Dravet syndrome, Doose syndrome or epilepsy with myoclonic atonic (previously astatic) seizures,

${ }^{1}$ Universidade de Campinas, Instituto Brasileiro de Neurociências e Neurotecnologia, Faculdade de Ciências Médicas, Departamento de Genética Médica, Campinas SP, Brazil;

${ }^{2}$ Universidade de Campinas, Instituto Brasileiro de Neurociências e Neurotecnologia, Faculdade de Ciências Médicas, Departamento de Neurologia, Campinas SP, Brazil.

Correspondence: Iscia Lopes-Cendes; Rua Tessalia Vieira de Camargo, 126; Cidade Universitária Zeferino Vaz / UNICAMP; $13083-887$ Campinas SP, Brasil; E-mail:icendes@unicamp.br

Conflict of interest: There is no conflict of interest to declare.

Support: This work was supported by research grants from FAPESP and CNPq. MCG is supported by a fellowship from FAPESP and CVS is supported by a studentship from CNPq.

Received 29 May 2015; Received in final form 01 July 2015; Accepted 20 July 2015. 
Lennox-Gastaut syndrome (LGS), epileptic encephalopathy with continuous spike-and-wave during sleep (CSWS), and Landau-Kleffner syndrome (LKS). As widely recognized, each one of these different clinical entities have specific characteristics, including mainly clinical and EEG features, which make it possible to clinically recognize them; however, recent developments in the field of molecular genetics are helping to determine that there are many intermediary phenotypes, which can represent a great diagnostic challenge to clinicians. Patients presenting these transitional or less characteristic phenotypes are probably those who will benefit most of the recently available genetic diagnostic tools, which will help determining diagnosis and establishing an etiology. However, even for patients with a clinically well-defined syndrome within the group of CEEs a positive genetic test can define etiology. Therefore, the main objective of this review is to present and discuss current knowledge regarding i) new molecular genetic findings in this group of disorders; ii) the complex phenotype-genotype correlations observed in the CEEs; and, most importantly, iii) the impact of these new genetic findings in clinical practice.

\section{MOST COMMON CEES}

Early myoclonic encephalopathy (EME) is a neonatal epilepsy syndrome characterized by onset of myoclonic seizures usually within the first month of life and abnormal neurological signs at birth or at the moment of seizure onset ${ }^{2}$. The EEG presents with suppression-burst pattern with short paroxysmal bursts and longer periods of suppression, enhanced during sleep ${ }^{2}$. The syndrome has a poor prognosis with progressive deterioration and early death.

Ohtahara syndrome (OS), also called early infantile epileptic encephalopathy, is an age-dependent epileptic encephalopathy characterized by tonic seizures with onset at the neonatal period and EEG showing suppression-burst pattern with longer periods of bursts and shorter periods of suppression ${ }^{2}$. The prognosis is poor, with significant neurological impairment or death. Children with OS might evolve to West syndrome².

Epilepsy of infancy with migrating focal seizures (EIMFS) is a rare epileptic syndrome characterized by onset of multifocal seizures within the first 6 months of life and an ictal EEG demonstrating seizures independently arising and moving sequentially from both hemispheres. The syndrome progresses as intractable seizures and further psychomotor delay ${ }^{3}$.

West syndrome (WS) is characterized by developmental delay, epileptic spasms and EEG showing hypsarrhythmia. It starts in the first year of life, usually after the third month. The spasms are usually refractory to anti-epileptic drugs, ACTH or steroids; therefore, the prognosis is often poor ${ }^{1}$.

Lennox-Gastaut syndrome (LGS) starts between 3 and 5 years-old. It is characterized by deterioration of cognitive and psychomotor skills, multiple seizure types (tonic, atonic, atypical absences, generalized tonic clonic and focal), andEEG during wakefulness showing diffuse slow spike-and-waves $(<2.5 \mathrm{~Hz})$. During sleep, EEG shows bursts of generalized fast spikes around $10 \mathrm{~Hz}^{4}$. Although LGS can evolve from WS, it may occur in a previously epilepsy free child. Both WS and LGS can be associated with structural lesions such as malformations of cortical development, vascular lesions, metabolic disorders, etc. However, several patients present with a normal MRI. Therefore, determining the etiology of CEEs in these patients represents an additional challenge.

Doose syndrome, or epilepsy with myoclonic atonic (previously astatic) seizures, is characterized by multiple seizure types such as atypical absence, atonic, tonic and myoclonic astatic seizures. Its onset is between 7 months and 6 years-old ${ }^{5}$, and the prognosis is variable. Disturbances in cognitive and psychomotor skills are often present. The EEG remains the best diagnostic tool available.

Dravet syndrome was described in 1978 under the name of severe myoclonic epilepsy of infancy ${ }^{6}$. It is characterized by febrile and afebrile generalized and unilateral, clonic or tonic clonic seizures, which occur in the first year of life in an otherwise normal infant. These can be later associated with myoclonus, atypical absences, and partial seizures, and high sensitivity even to low-degree fever is observed ${ }^{6,7}$. Between the first and fourth years of life, some degree of cognitive impairment and behavior abnormality is often present. Seizures are usually refractory to antiepileptic drug treatment. Photosensitivity may be present. However, photosensitivity can be difficult to evaluate because it may not be present during the whole course of the disease ${ }^{6}$.

Epileptic encephalopathy with continuous spike-and-wave during sleep (CSWS) is characterized by a typical EEG finding of continuous spike-and-wave discharges (usually diffuse, but sometimes focal) occurring in at least $85 \%$ of slow sleep in children with focal or, eventually, generalized seizures (electrical status epilepticus of sleep, ESES). Seizure onset usually occurs between 2 and 12 years and there is a marked neurological deterioration in cognitive, behavioral and/or motor domains ${ }^{8}$. The treatment must aim the disappearance of the ESES, which is the mechanism responsible for the encephalopathy.

Landau-Kleffner syndrome (LKS) or syndrome of acquired aphasia with convulsive disorder in children is an epileptic encephalopathy that occurs in previously normal children with normally developed age-appropriated language ${ }^{9}$. It is characterized by seizures and acquired aphasia, typically verbal auditory agnosia, with onset between 2 and 8 years. EEG during sleep of patients with LKS characteristically shows ESES.

\section{THE DIAGNOSIS OF CEE}

The diagnosis of CEEs is still based on clinical features and EEG findings as described above. However, until 
recently, the etiology in most patients was not established. The first important development to improve the determination of etiology in patients with CEE occurred in the years of 1980's with the advances in imaging techniques, especially the introduction of clinical MRI. These developments made it possible to perform in vivo diagnosis of malformations of cortical development. However, it also became clear that a significant proportion of patients with CEE do not have structural lesions ${ }^{1,7,10}$. It was only in the $21^{\text {st }}$ century that significant advances in molecular genetics enabled the discovery that many patients with CEE actually have mutations in specific genes ${ }^{11}$.

\section{RECENT DEVELOPMENTS IN THE GENETICS OF CEE}

Recent advances in molecular genetic technologies have allowed for the mapping and the discovery of several genes for different forms of epilepsies. Traditional approaches such as linkage analysis and candidate gene association studies enable to determine the chromosome position of genes potentially contributing to the disease by evaluating the segregation of genetic markers among affected individuals within large pedigrees or by comparing their allele frequencies between cohorts of affected and unaffected individuals. Over the last decade, new techniques for detecting variants associated with complex traits have emerged, such as genome wide association studies (GWAS), which interrogates a great number of single-nucleotide polymorphisms (SNPs) among a large group of individuals. DNA sequencing methods to detect potentially deleterious variants have also advanced from the capillary electrophoresis technology (Sanger sequencing) to the next generation high throughput techniques, allowing for massively parallel sequencing that may include either the entire genomic sequence (whole genome sequencing, WGS) or be restricted to the protein coding sequences (whole exome sequencing, WES). Structural variations, such as deletions or duplications named copy number variants (CNVs) are also currently widely investigated by chromosome-microarryas using SNP-array technologies or arrays for complete genome hybridization (array-CGH).

This plethora of molecular genetics tools has helped to unravel the genetic factors underlying epilepsies such as the CEEs. As the knowledge on the genes associated with this group of disorders develops, it becomes evident that genetic heterogeneity is present in CEE, with many genes identified as harboring causative mutations in different patients. In addition, a surprising complex relationship between gene/mutations and phenotypes has also emerged. Therefore, we highlight the need to further assess the impact of these new molecular genetic findings in clinical practice. Below, we outline the main potentially deleterious variants currently reported for the different CEE phenotypes. The reader will clearly notice that a single phenotype (as defined by clinical and EEG aspects) is frequently associated with different causative mutations in different patients, as well as that, in several instances, mutations in the same gene may cause different CEE syndromes, exemplifying well the complex nature of the genotype/phenotype relationship, which is still in need of further studies. A comprehensive table of the genes associated with the different CEE phenotypes is presented (Table).

Table. List of genes associated with different childhood epileptic encephalopathies (CEEs).

\begin{tabular}{llc}
\hline Gene & & \multicolumn{1}{c}{ Associated phenotype } \\
ADORA2A & Acute encephalopathy with biphasic seizures and late reduced diffusion (AESD) & 61 \\
ALG13 & Lennox-Gastaut Syndrome and/or Infantile Spasms & 62 \\
ARFGEF2 & West Syndrome & 63 \\
ARHGEF15 & Severe Early-onset Epilepsy & 64 \\
ARHGEF9 & Severe mental retardation and epilepsy & 65 \\
ARX & Lennox-Gastaut syndrome & $16 ; 29 ; 30$ \\
& Ohtahara Syndrome & 66 \\
ASAH1 & West Syndrome & $67 ; 68$ \\
C100rf2 & Childhood-onset Epilepsy or Early-onset encephalopathy \\
& Early Onset Encephalopathy & 62 \\
CACNA1A & Infantile onset Spinocerebellar Ataxia Syndrome & Lennox-Gastaut Syndrome and/or Infantile Spasms \\
CACNA2D2 & Early infantile epileptic encephalopathies \\
CASK & Ohtahara Syndrome & $69 ; 70$ \\
CDKL5/ & Early onset encephalopathy & 17 \\
STK9 & Infantile Spasms and Mental Retardation \\
& Lennox-Gastaut syndrome & $31 ; 71 ; 72 ; 73$ \\
CHD2 & West Syndrome & Dravet Syndrome \\
& Infantile Spasms & Lennox-Gastaut syndrome
\end{tabular}

Continue 
CHRNA7 Congenital retinal dysfunction, Refractory epilepsy, Encephalopathy, Mental retardation, Repetitive $76 ; 77 ; 78$ hand movements, Severe muscular hypotonia and Macrocytosis. Severe encephalopathy with seizures and hypotonia

CLCN4

Severe Early-onset Epilepsy

64

CNTNAP2

Focal Epilepsy with Regression

$\begin{array}{rl}64 & 64 \\ 79 & 79\end{array}$

$D C X$

Lennox-Gastaut Syndrome and/or Infantile Spasms

DOCK7

Epileptic Encephalopathy and Cortical Blindness

EEF1A2

ENG Severe Early-onset Epilepsy

Early Infantile Epileptic Encephalopathy with suppression-burst

Early Mioclonic Encephalopathy

ErbB4

Lennox-Gastaut Syndrome and/or Infantile Spasms

Childhood-onset Epilepsy or Early-onset encephalopathy

Rett syndrome with early-onset seizures

$82 ; 83$

Lennox-Gastaut Syndrome and/or Infantile Spasms

Doose syndrome

Dravet Syndrome

Generalized epilepsy with febrile seizures plus (GEFS+)

GNAO1 Epileptic Encephalopathy with involuntary movements

Lennox-Gastaut Syndrome and/or Infantile Spasms

GRIN2A

Epileptic encephalopathy with continuous spike-and-wave during sleep

Atypical rolandic epilepsy and speech impairment

Landau-Kleffner syndrome

GRIN2B Lennox-Gastaut Syndrome and/or Infantile Spasms

Mental retardation and/or epilepsy

HCN1

HDAC4

Early Infantile Epileptic Encephalopathy

Lennox-Gastaut Syndrome and/or Infantile Spasms

HNRNPU

Lennox-Gastaut Syndrome and/or Infantile Spasms

HOXD

Early Infantile Epileptic Encephalopathy without Mesomelic Dysplasia

IQSEC2

Lennox-Gastaut Syndrome and/or Infantile Spasms

JNK3

KCNH5

Severe Developmental Epileptic Encephalopathy (Lennox-Gastaut syndrome)

Severe Early-onset Epilepsy

KCNQ2 Early onset epileptic encephalopathy (EOEE)

Ohtahara Syndrome

KCNQ3 Benign Familial Neonatal Seizures (BFNS)

Early onset epileptic encephalopathy (EOEE)

KCNT1 Malignant migrating partial seizures of infancy (MMPSI)

Ohtahara Syndrome

KCTD7 Progressive Myoclonus Epilepsy

KLF13

Congenital retinal dysfunction, Refractory epilepsy, Encephalopathy, Mental retardation, Repetitive hand movements, Severe muscular hypotonia and Macrocytosis.

MAGI2 Early-onset Epileptic Encephalopathy Infantile spasms

MBD5

West Syndrome

MECP2

Early-onset Encephalopathy and Cortical Myoclonus

Lennox-Gastaut syndrome and Rett syndrome

MEF2C

MTOR

NECAP1

Severe Intellectual Disability and Early-onset Epileptic Encephalopathy

$56 ; 58 ; 86 ; 87 ; 88$

$88 ; 62$

89

62

$62 ; 90$

91

62

42

64

$18 ; 92 ; 93 ; 94$

$65 ; 95 ; 96$

$18 ; 22 ; 97$

$65 ; 98$

78

$99 ; 100 ; 101$

90

$41 ; 102$

103

62

104

62

105

$N R G 2$

PCDH19 Dravet Syndrome

Infantile or early childhood onset epilepsy in female patients

$5 ; 53 ; 106$

Lennox-Gastaut syndrome

PCDHG Hypotonia, Feeding difficulty in infancy, Severe developmental delay, and Epileptic/

105 nonepileptic Encephalopathy associated with Delayed Myelination

PIGA Early-onset Epileptic Encephalopathy

Ohtahara Syndrome

PIGQ

Early-onset epileptic encephalopathy

Malignant migrating partial seizures in infancy 


\begin{tabular}{|c|c|c|}
\hline PNKP & $\begin{array}{l}\text { Early-onset Epileptic Encephalopathy } \\
\text { Intractable Seizures and Developmental delay } \\
\text { West Syndrome }\end{array}$ & $100 ; 101 ; 107$ \\
\hline PNPO & Neonatal epileptic encephalopathy & 108 \\
\hline POLG1 & $\begin{array}{l}\text { Alpers syndrome } \\
\text { Childhood progressive encephalopathy } \\
\text { Severe Encephalopathy with Intractable Epilepsy }\end{array}$ & $109 ; 110$ \\
\hline PRRT2 & $\begin{array}{l}\text { Benign familial Infantile Epilepsy (BFIE) } \\
\text { Infantile convulsions with choreoathetosis (ICCA) } \\
\text { Paroxysmal kinesigenic dyskinesia (PKD) }\end{array}$ & $111 ; 112$ \\
\hline RB1 & Infantile Spasms and Retinoblastoma & 113 \\
\hline SCN1A & $\begin{array}{l}\text { Acute Encephalopathy } \\
\text { Doose Syndrome } \\
\text { Dravet Syndrome } \\
\text { Early Onset Epilepsy (EOE) } \\
\text { Generalized Epilepsy With Febrile Seizures Plus (GEFS+) } \\
\text { Lennox-Gastaut syndrome } \\
\text { Malformations of Cortical Development (MCDs) } \\
\text { Malignant Migrating Partial Seizures of Infancy } \\
\text { West Syndrome }\end{array}$ & $\begin{array}{l}11 ; 20 ; 43 ; 47 ; 64 ; \\
114 ; 115 ; 116 ; \\
117 ; 118 ; 119 ; 120\end{array}$ \\
\hline SCN1B & $\begin{array}{l}\text { Dravet Syndrome } \\
\text { Generalized epilepsy with febrile seizures plus (GEFS+) }\end{array}$ & $44 ; 52 ; 121$ \\
\hline SCN2A & $\begin{array}{l}\text { Dravet Syndrome } \\
\text { Generalized epilepsy with febrile seizures plus (GEFS+) } \\
\text { Intractable epilepsy } \\
\text { Lennox-Gastaut syndrome } \\
\text { Migrating focal seizures of infancy } \\
\text { Ohtahara Syndrome } \\
\text { West Syndrome }\end{array}$ & $\begin{array}{l}18 ; 19 ; 51 ; 65 ; 60 ; \\
122 ; 123\end{array}$ \\
\hline SCN8A & $\begin{array}{l}\text { Epilepsy of infancy with migrating focal seizures } \\
\text { Infantile epileptic encephalopathy and SUDEP } \\
\text { Lennox-Gastaut syndrome }\end{array}$ & $21 ; 62 ; 124$ \\
\hline SERPINI1 & Continuous Spike and Waves during slow-wave Sleep & 55 \\
\hline SLC19A3 & $\begin{array}{l}\text { Epileptic spasms in early infancy } \\
\text { Severe psychomotor retardation }\end{array}$ & 125 \\
\hline SLC25A22 & $\begin{array}{l}\text { Early myoclonic encephalopathy } \\
\text { Epilepsy of infancy with migrating focal seizures } \\
\text { Neonatal Epileptic Encephalopathy with Suppression Burst }\end{array}$ & $12 ; 24 ; 126$ \\
\hline SLC2A1 & $\begin{array}{l}\text { Doose Syndrome } \\
\text { GLUT1 deficiency with neurodevelopmental delay and severe ataxia }\end{array}$ & $46 ; 127$ \\
\hline SLC35A2 & Early-onset Epileptic Encephalopathy & 128 \\
\hline SLC9A6 & Continuous Spike and Waves during slow-wave Sleep and Christianson syndrome & 57 \\
\hline SNAP25 & Severe Static Encephalopathy, Intellectual disability, and Generalized Epilepsy & 129 \\
\hline SPTAN1 & West Syndrome & $39 ; 130$ \\
\hline SRGAP2 & Early infantile epileptic encephalopathy & 131 \\
\hline SRPX2 & Rolandic epilepsy associated with oral and speech dyspraxia and mental retardation & 132 \\
\hline STXBP1 & $\begin{array}{l}\text { Borderline Early myoclonic encephalopathy and Ohtahara Syndrome } \\
\text { Early infantile epileptic encephalopathy } \\
\text { Lennox-Gastaut syndrome } \\
\text { Ohtahara Syndrome } \\
\text { West Syndrome }\end{array}$ & $\begin{array}{l}14 ; 38 ; 62 ; 101 ; \\
133 ; 134\end{array}$ \\
\hline SYNGAP1 & Early-onset epileptic Encephalopathy & $45 ; 66$ \\
\hline SYNJ1 & Childhood-onset Epilepsy or Early-onset encephalopathy & 66 \\
\hline SZT2 & $\begin{array}{l}\text { Early-onset Epileptic Encephalopathy characterized by Refractory Epilepsy and Absent } \\
\text { Developmental Milestones }\end{array}$ & 135 \\
\hline TBC1D24 & $\begin{array}{l}\text { Familial Infantile Myoclonic Epilepsy } \\
\text { Focal epilepsy and Intellectual disability syndrome } \\
\text { Malignant Migrating Partial Seizures of Infancy (MMPSI) } \\
\text { Ohtahara Syndrome }\end{array}$ & $23 ; 136$ \\
\hline TCF4 & Pitt-Hopkins syndrome (PHS) & 137 \\
\hline TNK2 & Infantile onset Epilepsy and Intellectual Disability & 138 \\
\hline TOR1A & Early Infantile Epileptic Encephalopathy & 81 \\
\hline TRPM1 & $\begin{array}{l}\text { Congenital retinal dysfunction, Refractory epilepsy, Encephalopathy, Mental retardation, Repetitive } \\
\text { hand movements, Severe muscular hypotonia and Macrocytosis. }\end{array}$ & 78 \\
\hline
\end{tabular}




\section{Early myoclonic encephalopathy (EME)}

Up until the last decade, little about the etiology of EME was known, and a scarcity of familial cases had been reported. Linkage analysis of a family with severe neonatal epilepsies with suppression-burst pattern revealed genetic mapping to chromosome 11p15.5, followed by the identification of a missense mutation in the gene encoding a mitochondrial glutamate/H symporter, SLC25A22, cosegregating with the disease $^{12}$. The authors then performed SLC25A22 mutation screening in 25 additional EME patients, but found no mutation. Furthermore, a de novo translocation $\mathrm{t}(2 ; 6)(\mathrm{q} 34 ; \mathrm{p} 25.3)$ has been reported in a patient with EME and profound psychomotor delay ${ }^{13}$. Fluorescence in situ hybridization (FISH) analysis revealed that one breakpoint disrupts the erythroblastic leukemia viral oncogene homolog 4 gene ErbB4, involved in the regulation of cell growth, proliferation and differentiation and that have been associated with schizophrenia ${ }^{13}$. More recently, mutations in two other candidate genes for EME have been reported. Targeted capture and sequencing of candidate genes for early onset epileptic encephalopathy (EOEE) detected a de novo splice site mutation in the syntaxin binding protein 1 gene (STXBP1), involved in the neurotransmitters release regulation, in a borderline patient with EME/OS ${ }^{14}$. This gene is also involved in the etiology of other CEEs, as it will be further presented in this paper. The other candidate gene is PIGA, encoding an enzyme required for the biosynthesis of a phosphatidylinositol glycan anchor, in which a nonsense mutation with an uncertain mode of inheritance was identified by WES in a sporadic case of EME previously diagnosed as $\mathrm{OS}^{15}$.

\section{Ohtahara syndrome (OS)}

Although OS may arise from a variety of etiologies, mainly involving structural abnormalities, a number of different genes have recently been associated with this syndrome. The first report of a genetic basis for OS was a de novo 33-bp duplication identified by direct sequencing ${ }^{16}$. This deletion comprises the aristaless-related homeobox gene $A R X$, essential for the development of interneurons, and results in an expansion of the first polyalanine tract of the ARX protein. ARX mutations had already been implicated in a range of phenotypes including brain malformations with abnormal genitalia and nonsyndromic mental retardation, thus the identification of an $A R X$ mutation in OS suggests a continuum between these phenotypes, with a common pathological mechanism possibly caused by impairment in the $\gamma$-aminobutyric acid (GABA) ergic interneurons ${ }^{16}$. Further studies contributed to increase the knowledge on the association of $A R X$ with OS, with the report of additional mutations identified by direct sequencing. However, a percentage of OS cases still do not present $A R X$ mutations ${ }^{17}$. Copy number variations (CNVs) have also been implicated in the etiology of OS, such as a de novo $2 \mathrm{Mb}$ deletion at 9q33.3-q34.11 identified by aCGH and a 111-kb deletion at Xp11.4 detected by genomic microarray analysis ${ }^{17}$. Mutation analysis of the STXBP1 gene, included in the 9q33.3-q34.11 region, revealed de novo missense, frameshift and splice-site mutations ${ }^{14}$. The 111-kb deletion comprises the calcium/calmodulin-dependent serine protein kinase gene $C A S K^{17}$. Interestingly, a de novo translation initiation mutation in the same $C A S K$ gene was detected in a second patient with $\mathrm{OS}^{17}$. Recently, genes encoding ion channels have also been associated with OS. One of them is the gene encoding the voltage-gated potassium channel Kv7.2 (KCNQ2), in which de novo missense mutations were found in patients with OS and neonatal epileptic encephalopathies resembling $\mathrm{OS}^{18}$. Another ion channel associated with OS is the voltage-gated sodium channel Nav1.2 (SCN2A), in which de novo missense mutations were also identified ${ }^{18}$. Mutations in both $K C N Q 2$ and $S C N 2 A$ are involved in a wide clinical spectrum of EOEEs, which overlap each other including benign phenotypes such as benign familial neonatal seizures, but also severe forms of CEEs. Recently, a WGS study also revealed two novel genes for OS: KCNT1, which encodes the potassium channel KCa4.1, and $P I G Q$, encoding a subunit of an $\mathrm{N}$-acetylglucosaminyltransferase involved in the glycosylphosphatidyl inositol (GPI) biosynthesis ${ }^{18}$.

\section{Epilepsy of infancy with migrating focal seizures (EIMFS)}

The first genetic study in malignant EIMFS investigating genes encoding different ion channels yielded no deleterious mutations. Later, however, mutation screening of voltage-gated sodium channel subunit genes revealed de novo missense mutations in SCN2A (Nav1.2) ${ }^{19}$, SCN1A (Nav1.1) ${ }^{20}$ and $S C N 8 A(\operatorname{Nav1.6})^{21}$. In addition, WES analysis allowed for the detection of de novo missense mutations in another ion channel gene, KCNTI (KCa4.1) ${ }^{22}$. WES analysis also enabled the identification of novel candidate genes for EIMFS, such as the TBC1D24 gene ${ }^{23}$ and SLC25A22 $2^{24}$. Furthermore, CNVs appear to account for a few cases of EIMFS. Distinct studies revealed a $598 \mathrm{~Kb}$ microduplication at chromosome $16 \mathrm{p} 11.2^{25}$, an $11.06 \mathrm{Mb}$ deletion of chromosome 2q24.2q31.1, comprising more than 40 genes including $S C N 1 A^{20}$ and a deletion of chromosome 20p13, disrupting the phospholipase C, beta 1 gene $P L C B 1^{26}$. Even with these recent advances regarding the genetic basis of EIMFS, the etiology of a number cases remain unclear, as other studies investigating candidates genes failed to identify potential disease-causing mutations ${ }^{22}$.

\section{West syndrome (WS)}

The first evidence about the genetic basis of WS came from genetic linkage analysis, with the mapping of an X-linked form of WS to chromosome Xp11.4 and Xp21.3-Xp2227.28. Mutation screening of the $A R X$ gene located within the candidate region in families with X-linked WS revealed a 24-bp duplication; an expansion of seven tandem triplets repeats, both resulting in an additional polyalanine stretch; and a $1.517 \mathrm{bp}$ deletion promoting a frameshift ${ }^{29}$. Frameshift and missense 
mutations were subsequently found in the same $A R X$ gene in patients diagnosed with WS or those who evolved to WS from an OS phenotype ${ }^{30}$.

A second chromosomal locus for X-linked WS was identified distal to $A R X$ in the Xp22.3 region, with the subsequent report of two apparently balanced X;autosome translocations detected by FISH and Southern blot hybridization ${ }^{31}$. In both cases, the breakpoint mapped to the cyclin-dependent kinase-like 5 gene, CDKL5 (also known as serine/threonine kinase 9, STK9). However, screening for potentially deleterious CDKL5 mutations in additional WS cohorts yielded negative results. Other chromosomal anomalies associated with WS include partial $4 \mathrm{p}$ trisomy ${ }^{32}$, balanced translocations $\mathrm{t}(\mathrm{X} ; 18)(\mathrm{p} 22 ; \mathrm{p} 11.2)^{33}$ and $\mathrm{t}(2 ; 6)(\mathrm{p} 15 ; \mathrm{p} 22.3)^{34}$, microdeletions on chromosomes 9q34.11 and 15q13.3 ${ }^{35}$, duplications on chromosome $14^{36}$ and a $0.5 \mathrm{Mb}$ triplication (partial tetrasomy) of chromosome 17q25.3 ${ }^{37}$. Additionally, mutation screening of STXBP1 and the $\alpha$-II spectrin gene SPTAN1, both located within the microdeleted region on chromosome 9q34.11, revealed a de novo $S T X B P 1$ missense mutation ${ }^{38}$ and an inframe 3 bp de novo deletion, a 6 bp and a 9 bp de novo duplications in $S P T A N 1^{39}$ in patients with WS. However, further STXBPland SPTAN1 mutation screening in other cohorts revealed no mutations ${ }^{39}$. Other studies, usually single casereports, found mutations in several other genes. A few cases of mitochondrial DNA mutation have also been reported. This genetic heterogeneity could be explained by the multiple mechanisms/lesions which can ultimately lead to the WS phenotype, including malformations of cortical development and a primarily mitochondrial disorder.

\section{Lennox-Gastaut syndrome (LGS)}

The etiology of LGS is highly heterogeneous, with the majority of cases resulting from a brain structural abnormality, but also including genetic factors. Mutations in a variety of genes that might be associated with LGS or LGS-like phenotypes have been reported, although there is still scarcity of systematic genetic analyses of cohorts with LGS. Among these genes, some have been already associated with other types of CEEs, such as SCN1A, SCN2A, CHD2, CDKL5, ARX and $S T X B P 1$. However, other studies failed to detect causative mutations in patients with LGS in these candidate genes. Most of the mutations identified to date were detected using WES or targeted massively parallel sequencing, which also allowed for the identification of de novo mutations in several other genes.

Several pathological CNVs have also been identified in patients with LGS: a microduplication of 15q11-q13 was reported in patients with late-onset LGS ${ }^{40}$. Furthermore, a 22q13.3 deletion, a 2q23.1 deletion, a duplication encompassing the MECP2 gene, and a deletion including the chromodomain helicase DNA binding protein 2gene ( $\mathrm{CHD} 2)$, were also detected by aCGH in patients with $\mathrm{LGS}^{41}$. Another chromosome abnormality identified in a patient with a severe developmental delay and CEE consistent with LGS was a balanced translocation $\mathrm{t}(\mathrm{Y} ; 4)(\mathrm{q} 11.2 ; \mathrm{q} 21)$, which truncates the c-Jun N-terminal kinase 3 (JNK3) gene ${ }^{42}$.

\section{Doose syndrome}

Since the description of Doose syndrome, hereditary factors have been suspected of being involved, most likely presenting a polygenic inheritance. The hypothesis of a genetic etiology for this phenotype was later supported by studies showing affected members in families with generalized febrile seizures plus (GEFS+) harboring mutations in $S C N 1 A^{43}$, $S C N 1 B^{44}$ and GABRG2. However, only one member of each family investigated had Doose syndrome, and these individuals all had some atypical features. Moreover, subsequent studies of these candidate genes in sporadic and familial cases of Doose syndrome yielded no causative mutations. Additional studies investigating several other candidate genes also did not find causative mutations in patients with typical Doose syndrome.

To date, the majority of mutations associated with Doose syndrome were identified by target sequencing of $S C N 1 A$. In addition, two patients with Doose syndrome from the same large pedigree and a patient from another cohort showed missense mutations in $G A B R G 2^{45}$. This same study performed targeted massively parallel sequencing, which also enabled the identification of two de novo frameshift mutations in the CHD2 gene in two other patients with Doose syndrome $^{45}$. More recently, another gene has risen as a potential candidate for Doose syndrome, the $S L C 2 A 1$, which encodes the glucose transporter 1 (GLUT1), associated with a severe metabolic encephalopathy involving movement disorder and epilepsy $^{46}$. However, multiplex ligation-dependent probe amplification analysis (MLPA) did not reveal any structural rearrangements in $S L C 2 A 1$. The importance of seeking mutations in $S L C 2 A 1$ (GLUT1) is that these patients appear to respond to ketogenic diet which should be introduced when molecular diagnosis is confirmed ${ }^{7,46}$.

\section{Dravet syndrome}

Initially, linkage studies allowed for the identification of a locus for GEFS+ on chromosome 2, with subsequent detection of mutations in $S C N 1 A^{43}$. Clinical similarities between some patients with GEFS+ and Dravet syndrome motivated Claes et al. ${ }^{47}$ to further investigate mutations in SCN1A in patients with Dravet syndrome; thus, leading to the discovery of the first mutations in patients with Dravet syndrome. After this first report, several mutations in $S C N 1 A$ have been identified, with an overall frequency of mutations of approximately $70-80 \%$ in patients with Dravet syndrome. Therefore, SCN1A can be considered today as one of the most clinically relevant genes for genetic epilepsy ${ }^{48}$. Interestingly, mutations in $S C N 1 A$ in patients with Dravet syndrome frequently arise de novo; while in GEFS+ they are usually inherited as an autosomal dominant trait ${ }^{48}$. In addition, structural changes, CNVs, 
in SCN1A have been identified in a percentage of patients with Dravet syndrome, making it important to use more than one molecular technique to completely study potential deleterious changes in SCN1A in patients with this phenotype ${ }^{49}$.

Several studies have been performed to identify novel candidate genes for Dravet syndrome in SCN1A-negative patients. GABRG2 nonsense mutations have been identified, one in a family with GEFS+ and the other in dizygotic twins with Dravet syndrome ${ }^{50}$. However, another study failed to identify mutations in GABRG2 in a group of patients with Dravet syndrome. In addition, nonsense and missense mutations in $S C N 2 A$ were found in other cohorts ${ }^{51}$. Homozygous missense mutations in $S C N 1 B$ have also been identified ${ }^{52}$. Depienne et al. ${ }^{53}$ investigated micro-rearrangements by high-density SNP microarrays, which led to the discovery of a hemizygous deletion encompassing the protocadherin 19 gene (PCDH19). Subsequent PCDH19 target sequencing of additional subjects led to the identification of nonsense, frameshift and missense mutations. Recent WES and target sequencing studies analyzing cohorts of patients with CEE presenting some features of Dravet syndrome also revealed mutations in additional candidate genes. In addition, although Dravet syndrome is fundamentally considered a monogenic disease, the hypothesis of a complex heritance in some patients has recently emerged, with the identification of a few modulating genes that might be involved in the etiology of Dravet syndrome. Therefore, it is clear that even in a somewhat clinically well-defined phenotype such as Dravet syndrome the presence of marked genetic heterogeneity occurs.

\section{Epileptic encephalopathy with continuous spike-and-wave during sleep (CSWS)}

To date, little is known about the genetic basis of CSWS, with only one concordant pair of monozygotic twins report$\mathrm{ed}^{54}$ and few mutations identified. Later, though, a missense mutation in the neuroserpin gene SERPINI1 (also known as proteinase inhibitor 12 gene, PI12) was found in one patient who presented EEG activity suggestive of CSWS ${ }^{55}$.

It is currently recognized that there is a continuous spectrum comprising rolandic epilepsy, CSWS and LKS, suggesting that these phenotypes may share a common genetic etiology. This assumption is supported by the recent finding of different types of de novo or inherited mutations in GRIN2A in patients with CSWS belonging to families segregating epilepsy-aphasia syndrome disorders. In these families there were patients with variable phenotypes such as LKS, CSWSS, and atypical rolandic epilepsy and speech impairment ${ }^{56}$. GRIN2A encodes a subunit of the $N$-methyl-d-aspartate receptor, involved in the mediation of excitatory neurotransmission. More recently, an inherited homozygous splice-site mutation was identified in SLC9A6 in a patient with clinical features of Christianson syndrome and CSWS ${ }^{57}$. SLC9A6 encodes a sodium-hydrogen exchanger protein and had already been implicated in Christianson syndrome. In addition,
CNVs localized in genes that may be involved in predisposition to electrical status epilepticus during sleep have also been detected in patients with CSWS ${ }^{59}$.

\section{Landau-Kleffner syndrome (LKS)}

Up until recently, scarce information regarding the genetic factors involved in the etiology of LKS was available, with only few cases reported'. Lately, investigation of CNVs in LKS patients using array-CGH led to the identification of a 15q13.3 microdeletion ${ }^{59}$ and rare CNVs such as a microdeletion on chromosome 16p13, comprising the GRIN2A gene ${ }^{58}$. Subsequent GRIN2A mutation screening by target sequencing and WES revealed mutations in familial and isolated patients with $\mathrm{LKS}^{56}$. The identification of several de novo and inherited mutations in GRIN2A in both LKS and CSWSS supports the hypothesis of a clinical spectrum with a similar genetic bases for both disorders ${ }^{56}$.

\section{IMPACT OF THE NEW GENETIC FINDINGS IN CLINICAL PRACTICE}

As described above, the recent genetic findings in the group of CEEs are starting to shed some light on the different molecular mechanisms underlying several types of CEEs. It also becomes clear that genetic heterogeneity is a rule with different genes causing the same phenotype, as well as clinical heterogeneity with several genes causing different subtypes of CEE. The presence of genetic heterogeneity and clinical variability represent a major challenge when assessing the impact of these genetic discoveries in clinical practice. In addition, the vast range of molecular genetic technologies currently available can overwhelm the clinician, thus decision making regarding the most suitable technique for detecting genetic variants for each patient is not an easy task.

Nonetheless, the establishment of a correct molecular diagnosis has important practical applications as well as significant emotional impact for patients and parents. The fact that most abnormalities present in patients with CEE are $d e$ novo mutations has important implications for genetic counseling, since parents will most likely be found not to have these mutations and, therefore, the risk of recurrence in the same sibship will be the same as in the general population (except in rare cases of somatic mosaicism present in one of the parent's germ line $)^{48}$. Furthermore, one cannot minimize the positive emotional impact of a molecular diagnosis for the parents of children with CEE. In general, once a cause for the disease is determined, even when curative therapies cannot be adopted, parents stop searching for a diagnosis and can concentrate on treatment options and rehabilitation.

In addition, the specific diagnosis can influence treatment decisions such as the need to avoid sodium-blockers antiepileptic drugs such as carbamazepine and phenytoin in Dravet syndrome and SCN1A mutation-positive patients, or 
the specific indication of the use of ketogenic diet in patients with GLUT1 mutations ${ }^{48}$.

Although very genetically heterogeneous, there are a few genes for which specific mutation screening may still be useful in the context of CEEs. One of these is $S C N 1 A$, which harbors mutation in almost $80 \%$ of patients with Dravet syndrome. In addition, a few mutations in $S C N 1 A$ have also been reported in other types of CEEs. Therefore, one may consider genetic testing for $S C N 1 A$ useful in all CEEs, although the most important indication of $S C N 1 A$ genetic testing is still within the clinical limits of Dravet syndrome.

Another gene for which mutation screening may be very useful for clinical purposes in patients with CEEs is $A R X$. Mutations in this gene are mainly found in OS, but also in WS patients that evolved from OS or from families with OS affected members and even in a patient that later evolved to $\mathrm{LGS}^{30}$. It has been suggested that $A R X$ testing should be performed in children younger than one year old with OS and a movement disorder, as well as in children with unexplained neurodegeneration, progressive white matter loss, and cortical atrophy.

STXBP1 should also be considered for genetic testing in OS, as several mutations have been associated with this phenotype. For other CEE, however, the clinical utility of STXBP1 genetic test remains unclear, as mutations have been reported only in a single patient with WS not preceded by OS, and in a few patients with LGS and Dravet syndrome.

GRIN2A is another gene that has recently emerged as a strong candidate for epilepsy-aphasia spectrum disorders that include LKS and CSWS ${ }^{56}$. Thus, GRIN2A genetic testing appears to be particularly relevant for these phenotypes.

KCNQ2 and SCN2A genetic testing should be considered for patients with EOEE, although genotype-phenotype correlations are not yet well understood ${ }^{60}$. However, it has been recognized that $K C N Q 2$ screening should be performed for refractory neonatal seizures of unknown origin. In addition, mutations in PCDH19 should be considered in female patients with Dravet-like syndrome and some degree of cognitive delay and CDKL5 mutation should be contemplated in female patients with early onset severe intractable seizures or infantile spasms with or without Rett-like phenotype. Many other genes also appear to contribute to the etiology of certain specific phenotypes within the group of CEEs, but not in a frequency that justify a specific genetic testing.

It is important to consider that with the dissemination of genomic strategies of molecular diagnosis it is possible to adopt tests that will interrogate all candidates genes listed above at once. These can be performed as part of NGS gene panels, which should include the most suitable candidate genes for the phenotype studied ${ }^{60}$. Alternatively, high throughput strategies such as WES or even WGS can also be applied ${ }^{14,18}$. These can be useful especially when it is not clear which candidate gene is involved or for the discovery of new genes that might be responsible for the disease. The type of test indicated, target sequencing with gene panels or WES/WGS, will depend mainly on whether a specific clinical diagnosis has been achieved (e.g. Dravet syndrome) or not. Obviously, questions regarding costs are also relevant when ordering genetic tests and one should keep in mind that costs for WES/WGS are decreasing rapidly, making these alternative more attractive lately.

In addition, there are important questions regarding the most indicated molecular method for the different types of genetic defects sought ${ }^{48,49}$. In this way, it is important to point-out that a small percentage of patients with Dravet syndrome and mutations in $S C N 1 A$ have pathological CNVs instead of sequence mutations ${ }^{48,49}$. In addition, pathological CNVs have been widely reported in patients with different degrees of mental retardation associated or not with other clinical findings, including epilepsy. Since sequencing techniques can overlook CNVs, an alternative method such as chromosomal microarray should also be considered to complement genetic investigation ${ }^{48,49}$. Moreover, there are other limitations in the use of NGS, such as sequences of genes containing multiple repeats that may interfere with correct mapping and reading, thus resulting in low sequence coverage ${ }^{14}$. Therefore, the clinician should always be aware that even the most current technology in molecular diagnosis is not a guarantee of a flawless technique.

In conclusion, it is important to recognize that the most accurate technique for diagnosis may vary according to the genetic information already available and the phenotype investigated. When a potential candidate gene is more likely, one should consider targeted sequencing which may still be more cost-effective. However, in cases where there is scarce genetic information available, WES and WGS may reveal novel causative genes. In addition, there are a number of technical questions (e.g. whether important candidate genes will be well covered) that should be considered when using gene panels and WES in order to choose the most suitable technology. Furthermore, CNV analysis should also be considered when investigating patients with CEEs. 
1. Berg AT, Berkovic SF, Brodie MJ, Buchhalter J, Cross JH, Emde Boas W et al. Revised terminology and concepts for organization of seizures and epilepsies: Report of the ILAE Commission on Classification and Terminology, 2005-2009. Epilepsia. 2010;51(4):676-85. doi:10.1111/j.1528-1167.2010.02522.x

2. Ohtahara S, Yamatogi Y. Epileptic encephalopathies in early infancy with suppression-burst.J Clin Neurophysiol. 2003;20(6):398-407. doi:10.1097/00004691-200311000-00003

3. Coppola G, Plouin P, Chiron C, Robain O, Dulac O. Migrating partial seizures in infancy: a malignant disorder with developmental arrest. Epilepsia. 1995;36(10):1017-24. doi:10.1111/j.1528-1157.1995.tb00961.x

4. Lennox WG, Davis JP. Clinical correlates of the fast and the slow spike-wave electroencephalogram. Pediatrics. 1950;5(4):626-44.

5. Guerrini R, Mari F, Dravet C. Idiopathic myoclonic epilepies in infancy and early childhood. In: Bureau M, Genton P, Dravet C, Delgado-Escueta AV, Tassinari CA, Thomas P et al., editors. Epileptic syndromes in infancy, childhood and adolescence. 5th ed. Montrouge, France: John Libbey; 2012. p. 157-73.

6. Dravet C. Les épilepsies graves de l'enfant. Vie Med. 1978;8:543-8.

7. Commission on Classification and Terminology of the International League Against Epilepsy Proposal for revised classification of epilepsies and epileptic syndromes. Epilepsia. 1989;30(4):289-99.

8. Tassinari CA, Dravet C, Roger J. ESES-Encephalopathy related to electrical status epilepticus during sleep. Electroencephalogr Clin Neurophysiol. 1977;43(4):529-30.

9. Landau WM, Kleffner FR. Syndrome of acquired aphasia with convulsive disorder in children. Neurology. 1957;7(8):523-30. doi:10.1212/WNL.7.8.523

10. Dulac OJ, Chiron C. Malignant epileptic encephalopathies in children. Baillieres Clin Neurol. 1996;5(4):765-81.

11. Marini C, Mei D, Temudo T, Ferrari AR, Buti D, Dravet C et al. Idiopathic epilepsies with seizures precipitated by fever and SCN1A abnormalities. Epilepsia. 2007;48(9):1678-85. doi:10.1111/j.1528-1167.2007.01122.x

12. Molinari F, Raas-Rothschild A, Rio M, et al. Impaired mitochondrial glutamate transport in autosomal recessive neonatal myoclonic epilepsy. Am J Hum Genet. 2005;76(2):334-9. doi:10.1086/427564

13. Backx L, Ceulemans B, Vermeesch JR, Devriendt K, Van Esch H. Early myoclonic encephalopathy caused by a disruption of the neuregulin-1 receptor ErbB4. Eur J Hum Genet. 2009;17(3):378-82. doi:10.1038/ejhg.2008.180

14. Kodera H, Kato M, Nord AS, Walsh T, Lee M, Yamanaka G et. al. Targeted capture and sequencing for detection of mutations causing early onset epileptic encephalopathy. Epilepsia. 2013;54(7):1262-9. doi:10.1111/epi.12203

15. Kato M, Saitsu H, Murakami Y, Kikuchi K, Watanabe S, lai M et al. PIGA mutations cause early-onset epileptic encephalopathies and distinctive features. Neurology. 2014;82(18):1587-96. doi:10.1212/WNL.0000000000000389

16. Kato M, Saitoh S, Kamei A, Shiraishi H, Ueda Y, Akasaka M et al. A longer polyalanine expansion mutation in the ARX gene causes early infantile epileptic encephalopathy with suppression-burst pattern (Ohtahara syndrome). Am J Hum Genet. 2007;81 (2):361-6. doi:10.1086/518903

17. Saitsu H, Kato M, Osaka H, Moriyama N, Horita H, Nishiyama K et al. CASK aberrations in male patients with Ohtahara syndrome and cerebellar hypoplasia. Epilepsia. 2012;53(8):1441-9. doi:10.1111/j.1528-1167.2012.03548.x

18. Martin HC, Kim GE, Pagnamenta AT, Murakami Y, Carvill GL, Meyer E et al. Clinical whole-genome sequencing in severe early-onset epilepsy reveals new genes and improves molecular diagnosis. Hum Mol Genet. 2014;23(12):3200-11. doi:10.1093/hmg/ddu030

19. Dhamija R, Wirrell E, Falcao G, Kirmani S, Wong-Kisiel LC. Novel de novo SCN2A mutation in a child with migrating focal seizures of infancy. Pediatr Neurol. 2013;49(6):486-8. doi:10.1016/j.pediatrneurol.2013.07.004

20. Carranza Rojo D, Hamiwka L, McMahon JM, Dibbens LM, Arsov T, Suls A et al. De novo SCN1A mutations in migrating partial seizures of infancy. Neurology. 2011;77(4):380-3. doi:10.1212/WNL.0b013e318227046d

21. Ohba C, Kato M, Takahashi S, Lerman-Sagie T, Lev D, Terashima H et al. Early onset epileptic encephalopathy caused by de novo SCN8A mutations. Epilepsia. 2014;55(7):994-1000. doi:10.1111/epi.12668

22. McTague A1, Appleton R, Avula S, Cross JH, King MD, Jacques TS et al. Migrating partial seizures of infancy: expansion of the electroclinical, radiological and pathological disease spectrum. Brain. 2013;136(5):1578-91. doi:10.1093/brain/awt073

23. Milh M, Falace A, Villeneuve N, Vanni N, Cacciagli P, Assereto S et al. Novel compound heterozygous mutations in TBC1D24 cause familial malignant migrating partial seizures of infancy. Hum Mutat. 2013;34(6):869-72. doi:10.1002/humu.22318

24. Poduri A, Heinzen EL, Chitsazzadeh V, Lasorsa FM, Elhosary PC, LaCoursiere CM et al. SLC25A22 is a novel gene for migrating partial seizures in infancy. Ann Neurol. 2013;74(6):873-82. doi:10.1002/ana.23998

25. Bedoyan JK, Kumar RA, Sudi J, Silverstein F, Ackley T, lyer RK et al. Duplication 16p11.2 in a child with infantile seizure disorder. Am J Med Genet A. 2010;152A(6):1567-74. doi:10.1002/ajmg.a.33415

26. Poduri A, Chopra SS, Neilan EG, Elhosary PC, Kurian MA, Meyer E et al. Homozygous PLCB1 deletion associated with malignant migrating partial seizures in infancy. Epilepsia. 2012;53(8):e146-50. doi:10.1111/j.1528-1167.2012.03538.x

27. Claes S, Devriendt K, Lagae L, Ceulemans B, Dom L, Casaer P et al. The X-linked infantile spasms syndrome (MIM 308350) maps to Xp11.4-Xpter in two pedigrees. Ann Neurol. 1997;42(3):360-4. doi:10.1002/ana.410420313

28. Bruyere H, Lewis S, Wood S, MacLeod PJ, Langlois S. Confirmation of linkage in X-linked infantile spasms (West syndrome) and refinement of the disease locus to Xp21.3-Xp22.1. Clin Genet. 1999;55(3):173-81. doi:10.1034/j.1399-0004.1999.550305.x

29. Strømme P, Mangelsdorf ME, Shaw MA, Lower KM, Lewis SM, Bruyere $\mathrm{H}$ et al. Mutations in the human ortholog of Aristaless cause X-linked mental retardation and epilepsy. Nat Genet. 2002;30(4):441-5. doi:10.1038/ng862

30. Kato M, Koyama N, Ohta M, Miura K, Hayasaka K. Frameshift mutations of the ARX gene in familial Ohtahara syndrome. Epilepsia. 2010;51(9):1679-84. doi:10.1111/j.1528-1167.2010.02559.x

31. Kalscheuer VM, Tao J, Donnelly A, Hollway G, Schwinger E, Kübart S et al. Disruption of the serine/threonine kinase 9 gene causes severe X-linked infantile spasms and mental retardation. Am J Hum Genet. 2003;72(6):1401-11. doi:10.1086/375538

32. Gérard-Blanluet M, Romana S, Munier C, Le Lorc'h M, Kanafani S, Sinico M et al. Classical West "syndrome" phenotype with a subtelomeric $4 \mathrm{p}$ trisomy. Am J Med Genet A. 2004;130A(3):299-302. doi:10.1002/ajmg.a.30314

33. Akabori S, Takano T, Fujito H, Takeuchi Y. West syndrome in a patient with balanced translocation t(X;18)(p22;p11.2). Pediatr Neurol. 2007;37(1):64-6. doi:10.1016/j.pediatrneurol.2007.02.014

34. Vandeweyer G, Van der Aa N, Ceulemans B, Bon BW, Rooms L, Kooy RF. A de novo balanced $t(2 ; 6)(p 15 ; p 22.3)$ in a patient with West Syndrome disrupts a Inc-RNA. Epilepsy Res. 2012;99(3):346-9. doi:10.1016/j.eplepsyres.2011.12.009

35. Lacaze E, Gruchy N, Penniello-Valette MJ, Plessis G, Richard N, Decamp $M$ et al. De novo 15q13.3 microdeletion with cryptogenic West syndrome. Am J Med Genet A. 2013;161A(10):2582-7. doi:10.1002/ajmg.a.36085

36. Striano P, Paravidino R, Sicca F, Chiurazzi P, Gimelli S, Coppola A et al. West syndrome associated with $14 q 12$ duplications harboring FOXG1. Neurology. 2011;76(18):1600-2. doi:10.1212/WNL.0b013e3182194bbf 
37. Hackmann K, Stadler A, Schallner J, Franke K, Gerlach EM, Schrock E et al. Severe intellectual disability, West syndrome, Dandy-Walker malformation, and syndactyly in a patient with partial tetrasomy 17q25.3. Am J Med Genet A. 2013;161A(12):3144-9. doi:10.1002/ajmg.a.36155

38. Otsuka M, Oguni H, Liang JS, Ikeda H, Imai K, Hirasawa K et al. STXBP1 mutations cause not only Ohtahara syndrome but also West syndrome: result of Japanese cohort study. Epilepsia. 2010;51(12): 2449-52. doi:10.1111/j.1528-1167.2010.02767.x

39. Saitsu H, Tohyama J, Kumada T, Egawa K, Hamada K, Okada I et al. Dominant-negative mutations in alpha-II spectrin cause West syndrome with severe cerebral hypomyelination, spastic quadriplegia, and developmental delay. Am J Hum Genet. 2010;86(6):881-91. doi:10.1016/j.ajhg.2010.04.013

40. Rocha J, Guerra C, Oliveira R, Dória S, Rego R, Rosas MJ. Late-onset Lennox-Gastaut syndrome as a phenotype of 15q11.1q13.3 duplication. Epileptic Disord. 2012;14(2):159-62. doi:10.1684/epd.2012.0502.

41. Lund C, Brodtkorb E, Røsby O, Rødningen OK, Selmer KK. Copy number variants in adult patients with Lennox-Gastaut syndrome features. Epilepsy Res. 2013;105(1-2):110-7. doi:10.1016/j.eplepsyres.2013.01.009

42. Shoichet SA, Duprez L, Hagens O, Waetzig V, Menzel C, Herdegen Tet al. Truncation of the CNS-expressed JNK3 in a patient with a severe developmental epileptic encephalopathy. Hum Genet. 2006;118(5):559-67. doi:10.1007/s00439-005-0084-y

43. Escayg A, Heils A, MacDonald BT, Haug K, Sander T, Meisler MH. A novel SCN1A mutation associated with generalized epilepsy with febrile seizures plus -- and prevalence of variants in patients with epilepsy. Am J Hum Genet. 2001;68(4):866-73. doi:10.1086/319524

44. Wallace RH, Wang DW, Singh R, Scheffer IE, George AL Jr, Phillips HA et al. Febrile seizures and generalized epilepsy associated with a mutation in the Na+-channel beta1 subunit gene SCN1B. Nat Genet. 1998;19(4):366-70. doi:10.1038/1252

45. Carvill GL, Heavin SB, Yendle SC, McMahon JM, O’Roak BJ, Cook $J$ et al. Targeted resequencing in epileptic encephalopathies identifies de novo mutations in CHD2 and SYNGAP1. Nat Genet. 2013;45(7):825-30. doi:10.1038/ng.2646

46. Mullen SA, Suls A, De Jonghe P, Berkovic SF, Scheffer IE. Absence epilepsies with widely variable onset are a key feature of familial GLUT1 deficiency. Neurology. 2010;75(5):432-40. doi:10.1212/WNL.0b013e3181eb58b4

47. Claes L, Del-Favero J, Ceulemans B, Lagae L, Van Broeckhoven C, De Jonghe P. De novo mutations in the sodium-channel gene SCN1A cause severe myoclonic epilepsy of infancy. Am J Hum Genet. 2001;68(6):1327-32. doi:10.1086/320609

48. Ottman R, Hirose S, Jain S, Lerche H, Lopes-Cendes I, Noebels JL et al. Genetic testing in the epilepsies - report of the ILAE Genetics Commission. Epilepsia. 2010;51(4):655-70. doi:10.1111/j.1528-1167.2009.02429.x

49. Marini C, Scheffer IE, Nabbout R, Mei D, Cox K, Dibbens LM et al. SCN1A duplications and deletions detected in Dravet syndrome: implications for molecular diagnosis. Epilepsia. 2009;50(7):1670-8. doi:10.1111/j.1528-1167.2009.02013.x

50. Ishii A, Kanaumi T, Sohda M, Misumi Y, Zhang B, Kakinuma N et al. Association of nonsense mutation in GABRG2 with abnormal trafficking of GABAA receptors in severe epilepsy. Epilepsy Res. 2014;108(3):420-32. doi:10.1016/j.eplepsyres.2013.12.005

51. Shi X, Yasumoto S, Nakagawa E, Fukasawa T, Uchiya S, Hirose S. Missense mutation of the sodium channel gene SCN2A causes Dravet syndrome. Brain Dev. 2009;31(10):758-62. doi:10.1016/j.braindev.2009.08.009

52. Patino GA, Claes LR, Lopez-Santiago LF, Slat EA, Dondeti RS, Chen $\mathrm{C}$ et al. A functional null mutation of SCN1B in a patient with Dravet syndrome. J Neurosci. 2009;29(34):10764-78. doi:10.1523/JNEUROSCI.2475-09.2009

53. Depienne C, Bouteiller D, Keren B, Cheuret E, Poirier K, Trouillard O et al. Sporadic infantile epileptic encephalopathy caused by mutations in PCDH19 resembles Dravet syndrome but mainly affects females. PLoS Genet. 2009;5(2):e1000381. doi:10.1371/journal.pgen.1000381

54. Blennow G, Ors M. Case reports. In: Beaumanoir A, Bureau M, Deonna T, Mira L, Tassinari CA, editors. Continuous spikes nad waves during slow sleep/electrical status epilepticus during slow sleep: acquired epileptic aphasia and related conditions. London:John Libbey; 1995. p. 185-6.

55. Coutelier M, Andries S, Ghariani S, Dan B, Duyckaerts C, van Rijckevorsel Ket al. Neuroserpin mutation causes electrical status epilepticus of slow-wave sleep. Neurology. 2008;71(1):64-6. doi:10.1212/01.wnl.0000316306.08751.28

56. Lesca G, Rudolf G, Bruneau N, Lozovaya N, Labalme A, Boutry-Kryza $\mathrm{N}$ et al. GRIN2A mutations in acquired epileptic aphasia and related childhood focal epilepsies and encephalopathies with speech and language dysfunction. Nat Genet. 2013;45(9):1061-6. doi:10.1038/ng.2726

57. Zanni G, Barresi S, Cohen R, Specchio N, Basel-Vanagaite L, Valente $\mathrm{EM}$ et al. A novel mutation in the endosomal $\mathrm{Na}+/ \mathrm{H}+$ exchanger NHE6 (SLC9A6) causes Christianson syndrome with electrical status epilepticus during slow-wave sleep (ESES). Epilepsy Res. 2014;108(4):811-5. doi:10.1016/j.eplepsyres.2014.02.009

58. Lesca G, Rudolf G, Labalme A, Hirsch E, Arzimanoglou A, Genton $P$ et al. Epileptic encephalopathies of the Landau-Kleffner and continuous spike and waves during slow-wave sleep types: genomic dissection makes the link with autism. Epilepsia. 2012;53(9):1526-38. doi:10.1111/j.1528-1167.2012.03559.x

59. Kevelam SH, Jansen FE, Binsbergen E, Braun KP, Verbeek NE, Lindhout $D$ et al. Copy number variations in patients with electrical status epilepticus in sleep. J Child Neurol. 2012;27(2):178-82. doi:10.1177/0883073811416006

60. Nakamura K, Kato M, Osaka H, Yamashita S, Nakagawa E, Haginoya K et al. Clinical spectrum of SCN2A mutations expanding to Ohtahara syndrome. Neurology; 2013;81(11): 992-8. doi:10.1212/WNL.0b013e3182a43e57

61. Shinohara M, Saitoh M, Nishizawa D, Ikeda K, Hirose S, Takanashi J et al. ADORA2A polymorphism predisposes children to encephalopathy with febrile status epilepticus. Neurology. 2013;80(17):1571-6. doi:10.1212/WNL.0b013e31828f18d8

62. Epi4K Consortium; Epilepsy Phenome/Genome Project. De novo mutations in epileptic encephalopathies. Nature. 2013;501(7466):217-21. doi:10.1038/nature12439

63. Banne E, Atawneh O, Henneke M, Brockmann K, Gärtner J, Elpeleg $O$ et al. West syndrome, microcephaly, grey matter heterotopia and hypoplasia of corpus callosum due to a novel ARFGEF2 mutation. J Med Genet. 2013;50(11):772-5. doi:10.1136/jmedgenet-2013-101752

64. Veeramah KR, Johnstone L, Karafet TM, Wolf D, Sprissler R, Salogiannis $J$ et al. Exome sequencing reveals new causal mutations in children with epileptic encephalopathies. Epilepsia. 2013;54(7):1270-81. doi:10.1111/epi.12201

65. Lemke JR, Riesch E, Scheurenbrand T, Schubach M, Wilhelm C, Steiner I et al. Targeted next generation sequencing as a diagnostic tool in epileptic disorders. Epilepsia. 2012;53(8):1387-98. doi:10.1111/j.1528-1167.2012.03516.x

66. Dyment DA, Tétreault M, Beaulieu CL,Hartley T, Ferreira P, Chardon JW et al. Whole-exome sequencing broadens the phenotypic spectrum of rare pediatric epilepsy: a retrospective study. Clin Genet. 2014. doi:10.1111/cge.12464

67. Hakonen AH, Isohanni P, Paetau A, Herva R, Suomalainen A, Lönnqvist T. Recessive Twinkle mutations in early onset encephalopathy with mtDNA depletion. Brain. 2007;130(Pt 11):3032-40.

68. Lönnqvist T, Paetau A, Valanne L, Pinko H. Recessive twinkle mutations cause severe epileptic encephalopathy. Brain. 2009;132(6):1553-62. doi:10.1093/brain/awp045

69. Edvardson S, Oz S, Abulhijaa FA, Taher FB, Shaag A, Zenvirt S et al. Early infantile epileptic encephalopathy associated with 
a high voltage gated calcium channelopathy. J Med Genet. 2013;50(2):118-23. doi:10.1136/jmedgenet-2012-101223

70. Pippucci T, Parmeggiani A, Palombo F, Maresca A, Angius A, Crisponi $L$ et al. A novel null homozygous mutation confirms CACNA2D2 as a gene mutated in epileptic encephalopathy. PLoS One. 2013;8(12):e82154. doi:10.1371/journal.pone.0082154

71. Weaving LS, Christodoulou J, Williamson SL, Friend KL, McKenzie OL, Archer H. Mutations of CDKL5 cause a severe neurodevelopmental disorder with infantile spasms and mental retardation. Am J Hum Genet. 2004;75(6):1079-1093. doi:10.1086/426462

72. Buoni S, Zannolli R, Colamaria V, Macucci F, Bartolo RM, Corbini L. Myoclonic encephalopathy in the CDKL5 gene mutation. Clin Neurophysiol. 2006;117(1):223-7. doi:10.1016/j.clinph.2005.09.008

73. Nemos C, Lambert L, Giuliano F, Doray B, Roubertie A, Goldenberg A et al. Mutational spectrum of CDKL5 in early-onset encephalopathies:a study of a large collection of French patients and review of the literature. Clin Genet. 2009;76(4):357-71. doi:10.1111/j.1399-0004.2009.01194.x

74. Suls A, Jaehn JA, Kecskés A, Weber Y, Weckhuysen S, Craiu DC et al. De novo loss-of-function mutations in $\mathrm{CHD} 2$ cause a fever-sensitive myoclonic epileptic encephalopathy sharing features with Dravet syndrome. Am J Hum Genet. 2013;93(5):967-75. doi:10.1016/j.ajhg.2013.09.017

75. Lund C, Brodtkorb E, Øye AM3, Røsby O, Selmer KK. CHD2 mutations in Lennox-Gastaut syndrome. Epilepsy Behav. 2014;33:18-21.

76. Sharp AJ, Mefford HC, Li K, Baker C, Skinner C, Stevenson RE et al. A recurrent 15q13.3 microdeletion syndrome associated with mental retardation and seizures. Nat Genet. 2008;40(3):322-8. doi:10.1038/ng.93

77. Endris V, Hackmann K, Neuhann TM, Grasshoff U, Bonin M, Haug U et al. Homozygous loss of CHRNA7 on chromosome 15q13.3 causes severe encephalopathy with seizures and hypotonia. Am J Med Genet A. 2010;152A(11):2908-11. doi:10.1002/ajmg.a.33692

78. Spielmann M, Reichelt G, Hertzberg C, Trimborn M, Mundlos S, Horn D et al. Homozygous deletion of chromosome 15q13.3 including CHRNA7 causes severe mental retardation, seizures, muscular hypotonia, and the loss of KLF13 and TRPM1 potentially cause macrocytosis and congenital retinal dysfunction in siblings. Eur J Med Genet. 2011 Jul-Aug;54(4):e441-5. doi:10.1016/j.ejmg.2011.04.004

79. Mefford HC, Yendle SC, Hsu C, CookJ, Geraghty E, McMahon JM et al. Rare copy number variants are an important cause of epileptic encephalopathies. Ann Neurol. 2011;70(6):974-85. doi:10.1002/ana.22645

80. Perrault I, Hamdan FF, Rio M, Capo-Chichi JM, Boddaert N, Décarie JC et al. Mutations in DOCK7 in individuals with epileptic encephalopathy and cortical blindness. Am J Hum Genet. 2014;94(6):891-7. doi:10.1016/j.ajhg.2014.04.012

81. Campbell IM, Yatsenko SA, Hixson P, Reimschisel T, Thomas M, Wilson W et al. Novel 9 q34.11 gene deletions encompassing combinations of four Mendelian disease genes:STXBP1, SPTAN1, ENG, and TOR1A. Genet Med. 2012;14(10):868-76. doi:10.1038/gim.2012.65

82. Ariani F, Hayek G, Rondinella D, Artuso R, Mencarelli MA, SpanholRosseto A et al. FOXG1 is responsible for the congenital variant of Rett syndrome. Am J Hum Genet. 2008;83(1):89-93. doi:10.1016/j. ajhg.2008.05.015

83. Kortüm F, Das S, Flindt M, Morris-Rosendahl DJ, Stefanova I, Goldstein A et al. The core FOXG1 syndrome phenotype consists of postnatal microcephaly, severe mental retardation, absent language, dyskinesia, and corpus callosum hypogenesis. J Med Genet. 2011;48(6):396-406. doi:10.1136/jmg.2010.087528

84. Harkin LA, Bowser DN, Dibbens LM, Singh R, Phillips F, Wallace $\mathrm{RH}$ et al. Truncation of the GABA(A)-receptor gamma2 subunit in a family with generalized epilepsy with febrile seizures plus. Am J Hum Genet. 2002;70(2):530-6.

85. Nakamura K, Kodera H, Akita T, Shiina M, Kato M, Hoshino H et al. De Novo mutations in GNAO1, encoding a Goo subunit of heterotrimeric
G proteins, cause epileptic encephalopathy. Am J Hum Genet. 2013;93(3):496-505. doi:10.1016/j.ajhg.2013.07.014

86. Carvill GL, Regan BM, Yendle SC, O’Roak BJ, Lozovaya N, Bruneau N et al. GRIN2A mutations cause epilepsy-aphasia spectrum disorders. Nat Genet. 2013;45(9):1073-6. doi:10.1038/ng.2727

87. Lemke JR, Lal D, Reinthaler EM, Steiner I, Nothnagel M, Alber M et al. Mutations in GRIN2A cause idiopathic focal epilepsy with rolandic spikes. Nat Genet. 2013;45(9):1067-72.

88. Endele S, Rosenberger G, Geider K, Popp B, Tamer C, Stefanova I et al. Mutations in GRIN2A and GRIN2B encoding regulatory subunits of NMDA receptors cause variable neurodevelopmental phenotypes. Nat Genet. 2010;42(11):1021-6. doi:10.1038/ng.677

89. Nava C, Dalle C, Rastetter A, Striano P, Kovel CG, Nabbout R et al. De novo mutations in HCN1 cause early infantile epileptic encephalopathy. Nat Genet. 2014;46(6):640-5. doi:10.1038/ng.2952

90. Du X, An Y, Yu L, Liu R, Qin Y, Guo X et al. A genomic copy number variant analysis implicates the MBD5 and HNRNPU genes in Chinese children with infantile spasms and expands the clinical spectrum of 2q23.1 deletion. BMC Med Genet. 2014;15:62. doi:10.1186/1471-2350-15-62

91. Lim BC, Min BJ, Park WY, Oh SK, Woo MJ, Choi JS et al. A unique phenotype of 2q24.3-2q32.1 duplication:early infantile epileptic encephalopathy without mesomelic dysplasia.J Child Neurol. 2014;29(2):260-4. doi:10.1177/0883073813478659

92. Saitsu H, Kato M, Koide A, Goto T, Fujita T, Nishiyama Ket al. Whole Exome Sequencing Identifies KCNQ2. Ann Neurol. 2012;72(2):298-300.

93. Weckhuysen S, Mandelstam S, Suls A, Audenaert D, Deconinck T, Claes LR et al. KCNQ2 encephalopathy:emerging phenotype of a neonatal epileptic encephalopathy. Ann Neurol. 2012;71(1):15-25. doi:10.1002/ana.22644

94. Kato M, Yamagata T, Kubota M, Arai H, Yamashita S, Nakagawa T et al. Clinical spectrum of early onset epileptic encephalopathies caused by KCNQ2 mutation. Epilepsia. 2013;54(7):1282-7.

95. Soldovieri MV, Boutry-Kryza N, Milh M, Doummar D, Heron B, Bourel E et al. Novel KCNQ2 and KCNQ3 mutations in a large cohort of families with benign neonatal epilepsy:first evidence for an altered channel regulation by syntaxin-1A. Hum Mutat. 2014;35(3):356-67. doi:10.1002/humu.22500

96. Allen NM, Mannion M, Conroy J, Lynch SA, Shahwan A, Lynch B et al. The variable phenotypes of KCNQ-related epilepsy. Epilepsia. 2014;55(9):e99-105. doi:10.1111/epi.12715

97. Barcia G, Fleming MR, Deligniere A, Gazula VR, Brown MR, Langouet $M$ et al. De novo gain-of-function KCNT1 channel mutations cause malignant migrating partial seizures of infancy. Nat Genet. 2012;44(11):1255-9. doi:10.1038/ng.2441

98. Kousi M, Anttila V, Schulz A, Calafato S, Jakkula E, Riesch E et al. Novel mutations consolidate KCTD7 as a progressive myoclonus epilepsy gene. J Med Genet. 2012;49(6):391-9. doi:10.1136/jmedgenet-2012-100859

99. Marshall CR, Young EJ, Pani AM, Freckmann ML, Lacassie Y, Howald C et al. Infantile spasms is associated with deletion of the MAGI2 gene on chromosome 7q11.23-q21.11. Am J Hum Genet. 2008;83(1):106-11. doi:10.1016/j.ajhg.2008.06.001

100. Mastrangelo M, Leuzzi V. Genes of early-onset epileptic encephalopathies:from genotype to phenotype. Pediatr Neurol. 2012;46(1):24-31. doi:10.1016/j.pediatrneurol.2011.11.003

101. Nordli DR Jr. Epileptic encephalopathies in infants and children. J Clin Neurophysiol. 2012;29(5):420-4. doi:10.1097/WNP.0b013e31826bd961

102. Leuzzi V, Di Sabato ML, Zollino M, Montanaro ML, Seri S. Early-onset encephalopathy and cortical myoclonus in a boy with MECP2 gene mutation. Neurology. 2004;63(10):1968-70.

103. Saitsu H, Igarashi N, Kato M, Okada I, Kosho T, Shimokawa O et al. De novo 5q14.3 translocation 121.5-kb upstream of MEF2C in a patient with severe intellectual disability and early-onset epileptic 
encephalopathy. Am J Med Genet A. 2011;155A(11):2879-84. doi:10.1002/ajmg.a.34289

104. Alazami AM, Hijazi H, Kentab AY, Alkuraya FS. NECAP1 loss of function leads to a severe infantile epileptic encephalopathy. J Med Genet. 2014;51(4):224-8. doi:10.1136/jmedgenet-2013-102030

105. Shimojima K, Isidor B, Le Caignec C, Kondo A, Sakata S, Ohno $K$ et al. A new microdeletion syndrome of 5 q31.3 characterized by severe developmental delays, distinctive facial features, and delayed myelination. Am J Med Genet A. 2011;155A(4):732-6. doi:10.1002/ajmg.a.33891

106. Specchio N, Marini C, Terracciano A, Mei D, Trivisano M, Sicca F et al. Spectrum of phenotypes in female patients with epilepsy due to protocadherin 19 mutations. Epilepsia. 2011;52(7):1251-7. doi:10.1111/j.1528-1167.2011.03063.x

107. Shen J, Gilmore EC, Marshall CA, Haddadin M, Reynolds JJ, Eyaid W et al. Mutations in PNKP cause microcephaly, seizures and defects in DNA repair. Nat Genet. 2010;42(3):245-9. doi:10.1038/ng.526

108. Mills PB, Surtees RA, Champion MP, Beesley CE, Dalton N, Scambler PJ et al. Neonatal epileptic encephalopathy caused by mutations in the PNPO gene encoding pyridox(am)ine 5'-phosphate oxidase. Hum Mol Genet. 2005;14(8):1077-86. doi:10.1093/hmg/ddi120

109. Milone M, Massie R. Polymerase gamma 1 mutations:clinical correlations. Neurologist. 2010;16(2):84-91. doi:10.1097/NRL.0b013e3181c78a89

110. Isohanni P, Hakonen AH, Euro L, Paetau I, Linnankivi T, Liukkonen E et al. POLG1 manifestations in childhood. Neurology. 2011;76(9):811-5. doi:10.1212/WNL.0b013e31820e7b25

111. Heron SE, Ong YS, Yendle SC, McMahon JM, Berkovic SF, Scheffer IE et al. Mutations in PRRT2 are not a common cause of infantile epileptic encephalopathies. Epilepsia. 2013;54(5):e86-9. doi:10.1111/epi.12167

112. Djémié T, Weckhuysen S, Holmgren P, Hardies K, Van Dyck T, Hendrickx R et al. PRRT2 mutations:exploring the phenotypical boundaries. J Neurol Neurosurg Psychiatry. 2014;85(4):462-5. doi:10.1136/jnnp-2013-305122

113. Jones K, Minassian BA. Genetic testing in infantile spasms identifies a chromosome $13 q$ deletion and retinoblastoma. Pediatr Neurol. 2014;50(5):522-4. doi:10.1016/j.pediatrneurol.2013.11.018

114. Wallace RH, Hodgson BL, Grinton BE, Gardiner RM, Robinson R, Rodriguez-Casero V et al. Sodium channel alpha1-subunit mutations in severe myoclonic epilepsy of infancy and infantile spasms. Neurology. 2003;61(6):765-9.

115. Mulley JC, Scheffer IE, Petrou S, Dibbens LM, Berkovic SF, Harkin LA. SCN1A mutations and epilepsy. Hum Mutat. 2005;25(6):535-42.

116. Harkin LA, McMahon JM, Iona X, Dibbens L, Pelekanos JT, Zuberi SM et al. The spectrum of SCN1A-related infantile epileptic encephalopathies. Brain. 2007;130(3):843-52.

117. Ebach K, Joos H, Doose H, Stephani U, Kurlemann G, Fiedler B et al. SCN1A mutation analysis in myoclonic astatic epilepsy and severe idiopathic generalized epilepsy of infancy with generalized tonic-clonic seizures. Neuropediatrics. 2005;36(3):210-3.

118. Depienne C, Trouillard O, Saint-Martin C, et al. Spectrum of SCN1A gene mutations associated with Dravet syndrome: analysis of 333 patients. J Med Genet 2009;46(3):183-91. doi:10.1136/jmg.2008.062323

119. Takayanagi M, Haginoya K, Umehara N, Kitamura T, Numata Y, Wakusawa K et al. Acute encephalopathy with a truncation mutation in the SCN1A gene:a case report. Epilepsia. 2010 Sep;51(9):1886-8. doi:10.1111/j.1528-1167.2010.02600.x

120. Barba C, Parrini E, Coras R, Galuppi A, Craiu D, Kluger G et al. Co-occurring malformations of cortical development and SCN1A gene mutations. Epilepsia. 2014;55(7):1009-19. doi:10.1111/epi.12658

121. Ogiwara I, Nakayama T, Yamagata T, Ohtani H, Mazaki E, Tsuchiya $S$ et al. A homozygous mutation of voltage-gated sodium channel $\beta(I)$ gene SCN1B in a patient with Dravet syndrome. Epilepsia. 2012;53(12):e200-3. doi:10.1111/epi.12040
122. Ogiwara I, Ito K, Sawaishi Y, Osaka H, Mazaki E, Inoue I et al. De novo mutations of voltage-gated sodium channel alphall gene SCN2A in intractable epilepsies. Neurology. 2009;73(13):1046-53. doi:10.1212/WNL.0b013e3181b9cebc.

123. Matalon D, Goldberg E, Medne L, Marsh ED. Confirming an expanded spectrum of SCN2A mutations:a case series. Epileptic Disord. 2014;16(1):13-8. doi:10.1684/epd.2014.0641

124. Veeramah KR, O'Brien JE, Meisler MH, Cheng X, Dib-Hajj SD, Waxman SG et al. De novo pathogenic SCN8A mutation identified by whole-genome sequencing of a family quartet affected by infantile epileptic encephalopathy and SUDEP. Am J Hum Genet. 2012;90(3):502-10. doi:10.1016/j.ajhg.2012.01.006

125. Yamada K, Miura K, Hara K, Suzuki M, Nakanishi K, Kumagai Tet al. A wide spectrum of clinical and brain MRI findings in patients with SLC19A3 mutations. BMC Med Genet. 2010;11:171. doi:10.1186/1471-2350-11-171

126. Molinari F, Kaminska A, Fiermonte G, Boddaert N, Raas-Rothschild A, Plouin P et al. Mutations in the mitochondrial glutamate carrier SLC25A22 in neonatal epileptic encephalopathy with suppression bursts. Clin Genet. 2009;76(2):188-94. doi:10.1111/j.1399-0004.2009.01236.x

127. Klepper J, Engelbrecht V, Scheffer H, Knaap MS, Fiedler A.. GLUT1 deficiency with delayed myelination responding to ketogenic diet. Pediatr Neurol. 2007;37(2):130-3.

128. Kodera H, Nakamura K, Osaka H, Maegaki Y, Haginoya K, Mizumoto S et al. De novo mutations in SLC35A2 encoding a UDP-galactose transporter cause early-onset epileptic encephalopathy. Hum Mutat. 2013;34(12):1708-14. doi:10.1002/humu.22446

129. Rohena L, Neidich J, Truitt Cho M, Gonzalez KD, Tang S, Devinsky O et al. Mutation in SNAP25 as a novel genetic cause of epilepsy and intellectual disability. Rare Dis. 2013;1:e26314. doi:10.4161/rdis.26314

130. Nonoda Y, Saito Y, Nagai S, Sasaki M, Iwasaki T, Matsumoto N et al. Progressive diffuse brain atrophy in West syndrome with marked hypomyelination due to SPTAN1 gene mutation. Brain Dev. 2013;35(3):280-3. doi:10.1016/j.braindev.2012.05.002

131. Saitsu H, Osaka H, Sugiyama S, Kurosawa K, Mizuguchi T, Nishiyama $K$ et al. Early infantile epileptic encephalopathy associated with the disrupted gene encoding Slit-Robo Rho GTPase activating protein 2 (SRGAP2). Am J Med Genet A. 2012;158A(1):199-205. doi:10.1002/ajmg.a.34363

132. Roll P, Rudolf G, Pereira S, Royer B, Scheffer IE, Massacrier A et al. SRPX2 mutations in disorders of language cortex and cognition. Hum Mol Genet. 2006;15(7):1195-207.

133. Saitsu H, Kato M, Mizuguchi T, Hamada K, Osaka H, Tohyama J et al. De novo mutations in the gene encoding STXBP1 (MUNC181) cause early infantile epileptic encephalopathy. Nat Genet. 2008;40(6):782-8. doi:10.1038/ng.150

134. Pavone P, Spalice A, Polizzi A, Parisi P, Ruggieri M. Ohtahara syndrome with emphasis on recent genetic discovery. Brain Dev. 2012;34(6):459-68. doi:10.1016/j.braindev.2011.09.004

135. Basel-Vanagaite L, Hershkovitz T, Heyman E, Raspall-Chaure M, Kakar N, Smirin-Yosef P et al. Biallelic SZT2 mutations cause infantile encephalopathy with epilepsy and dysmorphic corpus callosum. Am J Hum Genet. 2013;93(3):524-9. doi:10.1016/j.ajhg.2013.07.005

136. Guven A, Tolun A. TBC1D24 truncating mutation resulting in severe neurodegeneration. J Med Genet. 2013;50(3):199-202. doi:10.1136/jmedgenet-2012-101313

137. Amiel J, Rio M, Pontual L, Redon R, Malan V, Boddaert N et al. Mutations in TCF4, encoding a class I basic helix-loop-helix transcription factor, are responsible for Pitt-Hopkins syndrome, a severe epileptic encephalopathy associated with autonomic dysfunction. Am J Hum Genet. 2007;80(5):988-93.

138. Hitomi Y, Heinzen EL, Donatello S, Dahl HH, Damiano JA, McMahon JM et al. Mutations in TNK2 in severe autosomal recessive infantile onset epilepsy. Ann Neurol. 2013;74(3):496-501. doi:10.1002/ana.23934 